2020 Global Marketing Conference at Seoul Proceedings: 478-479 (November 2020) https://doi.org/10.15444/GMC2020.04.06.01

\title{
THE IMPACT OF INFLUENCER MARKETING AND INSTAGRAMMERS ON CONSUMER PURCHASE INTENTIONS AND BRAND ATTITUDE
}

\author{
Ricardo Godinho Bilro, Instituto Universitário de Lisboa (ISCTE-IUL), Portugal ${ }^{1}$ \\ Sandra Maria Correia Loureiro, Instituto Universitário de Lisboa (ISCTE-IUL), Portugal ${ }^{2}$ \\ Filipa Rosado Pinto, Instituto Universitário de Lisboa (ISCTE-IUL), Portugal ${ }^{3}$ \\ Inês Costa, Instituto Universitário de Lisboa (ISCTE-IUL), Portugal ${ }^{4}$
}

\begin{abstract}
In the last few years, we have noticed the emergence of influencer marketing (Lanz, Goldenberg, Shapira, \& Stahl, 2019; Sokolova \& Kefi, 2019), specifically of how some of this arising-stars in the social media spectrum have become sources of advice for other consumers, resulting in opinion leaders for the brands they advocate (Casaló, Flavián, \& Ibáñez-Sánchez, 2018). As this trend is expected to continue in the near future, the current research focuses in one of the fastest-growing social media platforms - Instagram - (De Veirman, Cauberghe, \& Hudders, 2017; Sheldon, Rauschnabel, Antony, \& Car, 2017) to understand how Instagrammers and their posts have an impact on consumer's purchase decisions for the young-adult audiences. Additionally, this study also aims to understand if this content creation influences consumer's brand attitude (Faircloth, Capella, \& Alford, 2016), that is, in the consumer's opinion about a product or service of a specific brand.
\end{abstract}

To put forward our research and be able to withdraw some conclusions, two studies with distinct research methods were used: first, we resort to a qualitative study based on indepth interviews. In this, 30 female consumers with age-range between 19 and 30 years old where interviewed. From this first study, we are able not only to provide information about the impact of influencer's posts on consumer's purchase decisions and their brand attitude but also to present diverse, relevant aspects about the digital influencers and their connection with the audience, such as Instagrammer personality, followers and followees ratio, preference between following traditional celebrities or bloggers, among others.

Concerning the second study, we resort to a netnography followed by a data-mining technique, through a text-mining approach. In this analysis, around 1,000 comments were extracted from the Instagram account of 5 Portuguese digital influencers. Using the Meaning Cloud tool as support, the analysis of the topics and sentiments included in that comments was performed. Based on this second study, we can claim that female consumers show a clear intention of buying the products that the Instagrammer they are following promote.

\footnotetext{
${ }^{1}$ bilro.ricardo@gmail.com

${ }^{2}$ sandramloureiro@netcabo.pt

${ }^{3}$ Filipa.Rosado.Pinto@iscte-iul.pt

${ }^{4}$ inesmilheirocosta96@hotmail.com
} 
To conclude, based on our two studies and in line with previous research (e.g., Chu \& Kamal, 2008; Grewal \& Stephen, 2019), it is noticeable that the digital influencers' posts on Instagram have an impact on the consumer's purchase intentions, especially concerning young female consumers. Regarding brand attitude, it is also clear that consumers tend to change their opinion towards a brand (positively or negatively) if a specific influencer promotes/demotes it.

Keywords: influencer marketing, Instagram, purchase decision, brand Attitude

\section{References}

Casaló, L. V, Flavián, C., \& Ibáñez-Sánchez, S. (2018). Influencers on Instagram: Antecedents and consequences of opinion leadership. Journal of Business Research, In press. https://doi.org/10.1016/j.jbusres.2018.07.005

Chu, S.-C., \& Kamal, S. (2008). The effect of perceived blogger credibility and argument quality on message elaboration and brand attitudes: An exploratory study. Journal of Interactive Advertising, 8(2), 26-37. https://doi.org/10.1080/15252019.2008.10722140

De Veirman, M., Cauberghe, V., \& Hudders, L. (2017). Marketing through instagram influencers: The impact of number of followers and product divergence on brand attitude. International Journal of Advertising, 36(5), 798-828. https://doi.org/10.1080/02650487.2017.1348035

Faircloth, J. B., Capella, L. M., \& Alford, B. L. (2016). The Effect of Brand Attitude and Brand Image on Brand Equity. Journal of Marketing Theory and Practice, 9(3), 6175. https://doi.org/10.1080/10696679.2001.11501897

Grewal, L., \& Stephen, A. T. (2019). In Mobile We Trust: The Effects of Mobile Versus Nonmobile Reviews on Consumer Purchase Intentions. Journal of Marketing Research, In press, 1-18. https://doi.org/10.1177/0022243719834514

Lanz, A., Goldenberg, J., Shapira, D., \& Stahl, F. (2019). Climb or Jump: Status-Based Seeding in User-Generated Content Networks. Journal of Marketing Research, 56(3), 361-378. https://doi.org/10.1177/0022243718824081

Sheldon, P., Rauschnabel, P. A., Antony, M. G., \& Car, S. (2017). A cross-cultural comparison of Croatian and American social network sites: Exploring cultural differences in motives for Instagram use. Computers in Human Behavior, 75, 643651. https://doi.org/http://dx.doi.org/10.1016/j.chb.2017.06.009 0747-5632/C

Sokolova, K., \& Kefi, H. (2019). Instagram and YouTube bloggers promote it, why should I buy? How credibility and parasocial interaction influence purchase intentions. Journal of Retailing and Consumer Services, (January). https://doi.org/10.1016/j.jretconser.2019.01.011 